\title{
Gastrocnemius Myalgia as a Rare Initial Manifestation of Crohn's Disease
}

\author{
Atsumu Osada ${ }^{1}$, Hiroaki Yamada ${ }^{2}$, Sayuri Takehara ${ }^{3}$, Yuuichiro Tozuka ${ }^{4}$, Taito Fukushima ${ }^{4}$, \\ Hiroyuki $\mathrm{Oka}^{3}$, Hiroshi Okazaki ${ }^{3}$ and Shohei Nagaoka ${ }^{1}$
}

\begin{abstract}
:
The initial symptoms of Crohn's disease (CD) sometimes present as extraintestinal lesions, which can be a diagnostic challenge for physicians. Painful legs, known as "gastrocnemius myalgia syndrome", are rare complications that often precede abdominal manifestations. We herein report the case of a 38-year-old man who presented with bilateral leg myalgia lasting for 4 months. Magnetic resonance imaging showed abnormal intensity, and a muscle biopsy revealed inflammatory cell infiltration. Abdominal symptoms appeared three months after the myalgia onset, and the diagnosis of CD was confirmed later by endoscopic and radiological findings. To our knowledge, this is the first description of gastrocnemius myalgia syndrome in Japan.
\end{abstract}

Key words: Crohn's disease, gastrocnemius myalgia syndrome, extraintestinal manifestation

(Intern Med 57: 2001-2006, 2018)

(DOI: 10.2169/internalmedicine.0327-17)

\section{Introduction}

Crohn's disease (CD) is an inflammatory disorder that manifests as discontinuous chronic granulomatous lesions, mainly in the digestive tract, extending from the oral cavity to the anus (1). Recent studies have shown that the development of CD is associated with a genetic predisposition and environmental factors, such as luminal microorganisms and enteric antigens (2), but the detailed etiology is still unclear.

Extraintestinal manifestations of $\mathrm{CD}$, especially those involving the joints, eyes, skin, and hepatobiliary system, are common and have been reported in $20-40 \%$ of patients (3). Less frequently, complications in vital organs are described, such as glomerular nephritis, especially IgA nephropathy, central nervous system lesions, and lung involvement $(4,5)$.

Gastrocnemius myalgia is a rare extraintestinal manifestation of $\mathrm{CD}$, described in only 11 other published cases (4, 6-14), that affects the musculoskeletal system. To our knowledge, the present case is the first description of typical gastrocnemius myalgia syndrome in a patient with CD in Japan.

\section{Case Report}

A 38-year-old man with no medical history presented to our hospital with myalgia in the bilateral lower extremities lasting for 4 months. One month before his visit, the patient experienced abdominal discomfort and had loose stools two or three times daily. He denied any bloody stools.

A physical examination revealed no abnormalities in the vital signs, and there were no abnormal findings on an examination of the head, neck, chest, abdomen, skin mucosa, and joints. There were no oral ulcers or anal lesions, such as anal fistula. Although the patient reported severe tenderness in both lower extremities, muscle weakness and abnormal tendon reflexes were not observed.

The laboratory findings are shown in Table 1. In brief, markers of inflammation were elevated, and hypoalbuminemia was observed. Although aldolase was mildly elevated, the serum creatine kinase level was within the reference value. Furthermore, the presence of fecal occult blood was confirmed twice. Magnetic resonance imaging showed highintensity areas in the bilateral gastrocnemius and soleus

\footnotetext{
${ }^{1}$ Department of Rheumatology, Yokohama Minami Kyosai Hospital, Japan, ${ }^{2}$ Department of Gastroenterology, Kosinkai Shiomidai Hospital, Japan, ${ }^{3}$ Department of Gastroenterology, Yokohama Minami Kyosai Hospital, Japan and ${ }^{4}$ Department of Gastroenterology, Kanagawa Cancer Center, Japan

Received: October 7, 2017; Accepted: December 5, 2017; Advance Publication by J-STAGE: February 28, 2018

Correspondence to Dr. Atsumu Osada, atsumu-osada-8074@hotmail.co.jp
} 
Table 1. Laboratoy Findings.

\begin{tabular}{lclr}
\hline WBC & $9,300(/ \mu \mathrm{L})$ & $\mathrm{Ca}$ & $9.8(\mathrm{mg} / \mathrm{dL})$ \\
lymphocytes & $23.0(\%)$ & ESR $(1 \mathrm{~h})$ & $48(\mathrm{~mm})$ \\
neutrophils & $67.0(\%)$ & CRP & $5.52(\mathrm{mg} / \mathrm{dL})$ \\
monocytes & $8.0(\%)$ & IgG/IgA/IgM & $1,168 / 241 / 191(\mathrm{mg} / \mathrm{dL})$ \\
eosinophils & $2.0(\%)$ & RF & $21(\mathrm{U} / \mathrm{mL})$ \\
$\mathrm{RBC}$ & $498\left(\times 10^{4} / \mu \mathrm{L}\right)$ & ANA & $(-)$ \\
$\mathrm{Hb}$ & $14.5(\mathrm{~g} / \mathrm{dL})$ & CH50 & $>50(\mathrm{U} / \mathrm{mL})$ \\
$\mathrm{Ht}$ & $43.4(\%)$ & antSS-A/SS-BAb & $1.2 / 2.3(\mathrm{U} / \mathrm{mL})$ \\
$\mathrm{Plt}$ & $53.4\left(\times 10^{4} / \mu \mathrm{L}\right)$ & antiJo-1Ab & $1(\mathrm{U} / \mathrm{mL})$ \\
$\mathrm{TP} / \mathrm{Alb}$ & $7.2 / 3.5(\mathrm{~g} / \mathrm{dL})$ & MPO-ANCA & $<9.0(\mathrm{U} / \mathrm{mL})$ \\
$\mathrm{AST} / \mathrm{ALT} / \mathrm{LDH}$ & $14 / 10 / 226(\mathrm{U} / \mathrm{L})$ & PR3-ANCA & $<3.5(\mathrm{U} / \mathrm{mL})$ \\
$\mathrm{ALP} / \gamma-\mathrm{GTP}$ & $209 / 23(\mathrm{U} / \mathrm{dL})$ & CMV pp65 $(\mathrm{C} 10 / \mathrm{C} 11)$ & $0 / 0$ \\
$\mathrm{~T}-\mathrm{Bil}$ & $0.6(\mathrm{mg} / \mathrm{dL})$ & T-SPOT TB & $(-)$ \\
$\mathrm{CK} / \mathrm{Ald}$ & $36 / 5.70(\mathrm{U} / \mathrm{L})$ & FOBT & $(+) /(+)$ \\
$\mathrm{BUN} / \mathrm{Cr} / \mathrm{UA}$ & $13.2 / 0.91 / 5.0(\mathrm{mg} / \mathrm{dL})$ & stool culture & normal flora \\
Na/K/Cl & $137 / 4.7 / 96.6(\mathrm{mEq} / \mathrm{L})$ & & \\
\hline
\end{tabular}
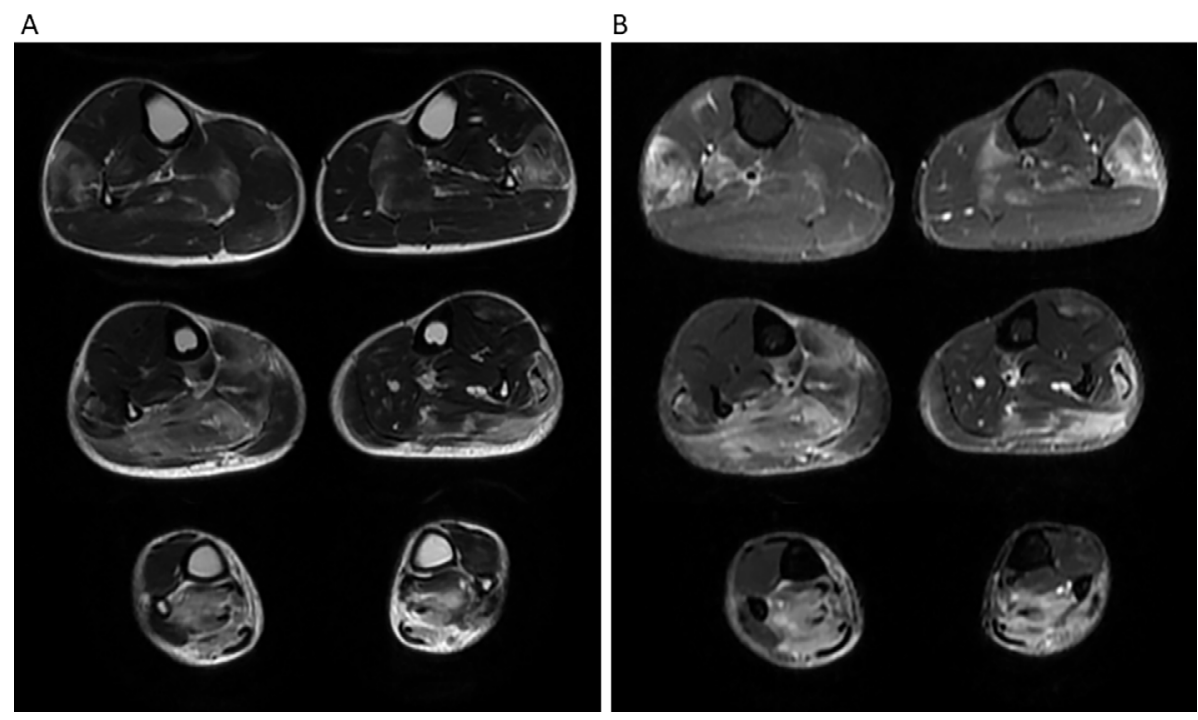

Figure 1. Magnetic resonance imaging showing $\mathrm{T} 2$ wedge (A) and short tau inversion recovery (B) images of the lower extremities. High-intensity areas are observed in the bilateral gastrocnemius, soleus, and long peroneal muscles.

muscles in T2 wedge and short tau inversion recovery images (Fig. 1). A muscle biopsy of the right soleus muscle showed endomysial lymphocytic infiltration and perivascular lymphocyte infiltration in connective tissue around the muscle, but the infiltration into the myofibers was not severe (Fig. 2). Abdominal computed tomography revealed submucosal edema in the ileocecal region and the ascending colon. Colonoscopy revealed longitudinal ulcers accompanied by sloughing, multiple multiform aphthae, and mucosal redness around the ileocecal region and the ascending colon (Fig. 3). A cobblestone appearance was not observed. The mucosal findings were normal from the transverse colon to the anus. A pathologic examination revealed moderate inflammatory cell infiltration in the interstitium of terminal ileum and the ascending colon as well as disturbance of the cryptic alignment in the ascending colon. There were no granulomas or crypt abscesses. Small bowel follow-through showed an approximately five-centimeter-long ulcer running longitudinally on the mesenteric side of the terminal ileum (Fig. 4).

Esophagogastroduodenoscopy revealed H1-stage ulcers in the lesser curvature of the pyloric region and the angular notch. H2-stage ulcers were observed on the front wall of the cardia. Bamboo-joint appearance and notch sign were not seen in the duodenum. Atrophic gastritis with a positive rapid urease test was observed. Stool cultures showed normal bacterial flora and were negative for Entamoeba histolytica. The patient was negative for cytomegalovirus antigen in the blood, and the T-SPOT $\mathrm{TB}^{\circledR}$ interferon $\gamma$ release test was also negative.

Based on the diagnostic criteria of the Ministry of Health, Labor and Welfare in Japan, the patient's diagnosis was confirmed as CD. Because of the typical clinical presentation, 
A

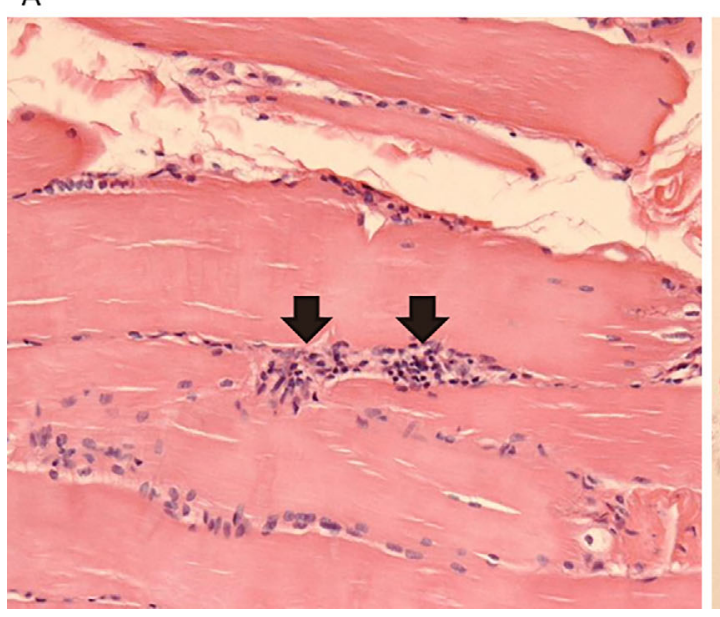

B

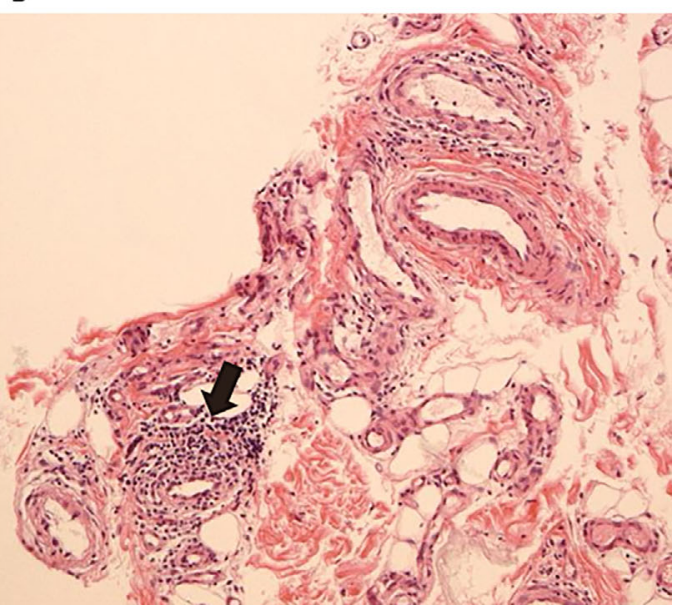

Figure 2. A pathologic examination of a biopsy specimen from the right soleus muscle. Mild lymphocytic infiltration in the endomysium (black arrow) is observed [Hematoxylin and Eosin (H\&E) staining, $\times 200](A)$. Moderate perivascular lymphocyte infiltration without necrotizing vasculitis is observed in the connective tissue around the muscle (H\&E staining, $\times 40)(B)$.

A

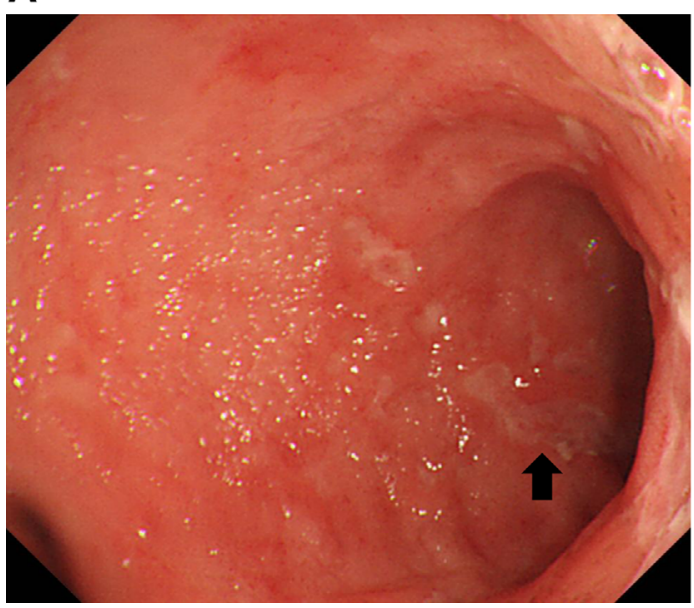

B

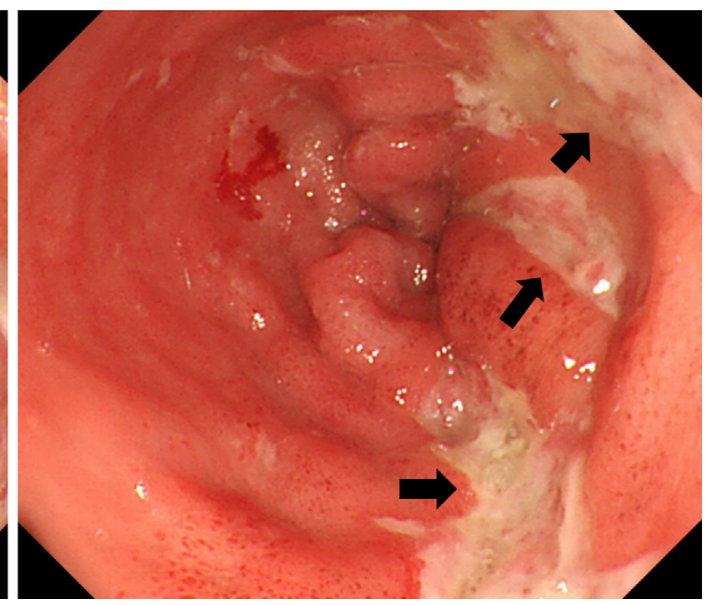

Figure 3. Colonoscopy of the terminal ileum (A) and cecum (B). Note the presence of longitudinal ulcers (arrow) accompanied by slough, multiple multiform aphthae, and mucosal redness.

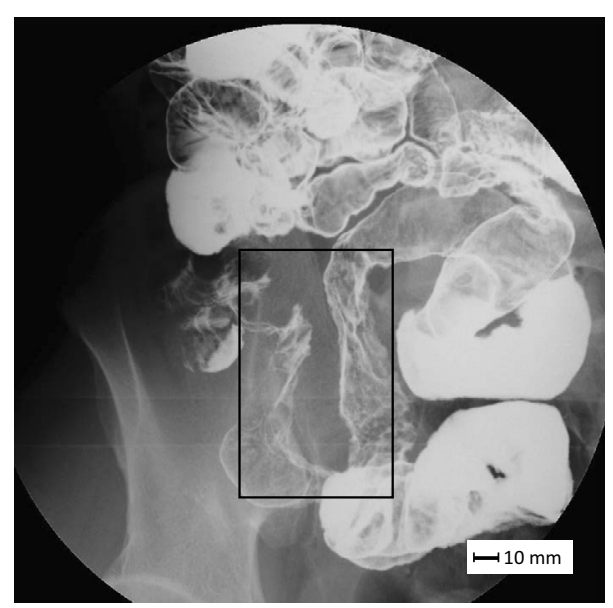

Figure 4. Small bowel follow-through showed an approximately five-centimeter-long ulcer running longitudinally on the mesenteric side of the terminal ileum (boxed). the lower extremity pain was considered to be due to gastrocnemius myalgia syndrome. An elemental diet, 5aminosalicylic acid, and $30 \mathrm{mg} /$ day prednisolone were initiated, which led to immediate improvements in the myalgia, loose stools, and elevated serum markers of inflammation. Colonoscopy performed after one month of treatment confirmed improvement in the mucosal lesions, and magnetic resonance imaging confirmed improvement of the lesions in the lower extremities. After the initial therapy, minor flare of myalgia and loose stools were observed, which were treated effectively with 5-aminosalicylic acid 1,500 mg/day and a low-dose increase in prednisolone and azathioprine. Helicobacter pylori infection was successfully treated with proton pump inhibitor, clarithromycin, and amoxicillin. The clinical course of this case is shown in Fig. 5. 


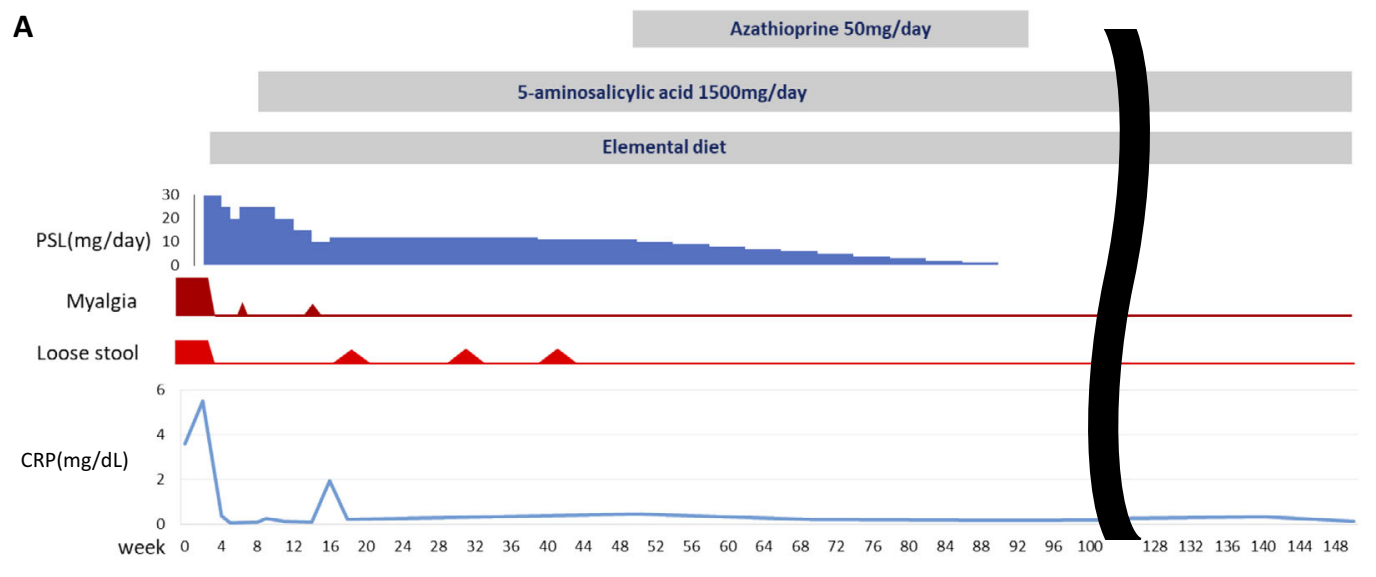

B

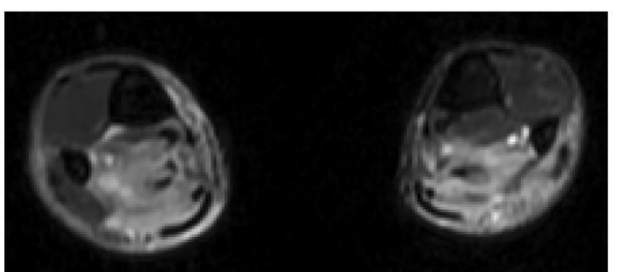

C

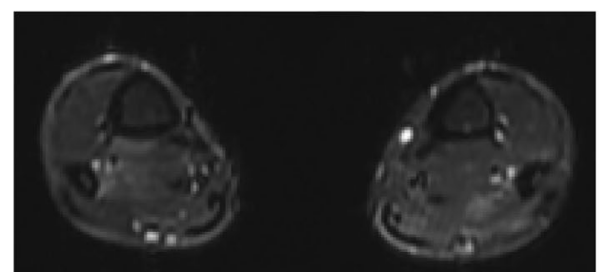

Figure 5. The clinical course of our case (A). Magnetic resonance imaging abnormalities in the legs on admission (B) improved in a month $(C)$.

Table 2. Reported Cases of Gastrocnemius Myalgia Syndrome.

\begin{tabular}{|c|c|c|c|c|c|c|c|c|}
\hline Reference & $\begin{array}{l}\text { Sex/ } \\
\text { age }\end{array}$ & $\begin{array}{c}\text { Site of } \\
\text { involvement }\end{array}$ & $\begin{array}{l}\text { past CD } \\
\text { diagnosis } \\
\text { at GMS } \\
\text { onset }\end{array}$ & $\begin{array}{l}\text { abdominal } \\
\text { symptom } \\
\text { at GMS } \\
\text { onset }\end{array}$ & $\begin{array}{l}\text { serum } \\
\text { CK } \\
\text { elevation }\end{array}$ & $\begin{array}{l}\text { Other extra- } \\
\text { intestinal } \\
\text { involvement }\end{array}$ & $\begin{array}{l}\text { Muscle biopsy } \\
\text { findings }\end{array}$ & Treatment \\
\hline [13] & $\mathrm{M} / 44$ & Bilateral & $(+)$ & NA & $(-)$ & Joint & $\begin{array}{l}\text { Granulomatous } \\
\text { myositis }\end{array}$ & PSL $80 \mathrm{mg} /$ day \\
\hline [11] & $\mathrm{M} / 19$ & NA & $(-)$ & $(+)$ & $(-)$ & NA & $\begin{array}{l}\text { Necrotizing } \\
\text { vasculitis }\end{array}$ & PSL $60 \mathrm{mg} /$ day \\
\hline [12] & $\mathrm{F} / 32$ & Left & $(+)$ & $(+)$ & $(-)$ & Joint, skin & $\begin{array}{l}\text { Nongranulomatous } \\
\text { myositis }\end{array}$ & $\begin{array}{l}\text { PSL } 25 \mathrm{mg} / \text { day (ineffective), switched } \\
\text { to } 60 \mathrm{mg} / \text { day }\end{array}$ \\
\hline [9] & $\mathrm{M} / 50$ & Bilateral & $(-)$ & $(+)$ & $(-)$ & $(-)$ & Not done & PSL $30 \mathrm{mg} /$ day \\
\hline [7] & $\mathrm{M} / 41$ & Bilateral & $(-)$ & $(-)$ & $(-)$ & $(-)$ & $\begin{array}{l}\text { Granulomatous } \\
\text { myositis, mild } \\
\text { mitochondrial } \\
\text { changes }\end{array}$ & No respose to steroids and NSAIDs \\
\hline [8] & $\mathrm{F} / 21$ & Bilateral & $(-)$ & $(+)$ & $(-)$ & Joint, skin & $\begin{array}{l}\text { Non-necrotizing } \\
\text { vasculitis }\end{array}$ & $\begin{array}{l}\text { PSL } 1 \mathrm{mg} / \mathrm{kg} / \text { day. Recurrence at PSL } \\
0.5 \mathrm{mg} / \mathrm{kg} / \mathrm{day} \text {, switched to } \\
\text { azathioprine } 100 \mathrm{mg} / \text { day }\end{array}$ \\
\hline [8] & $\mathrm{F} / 26$ & Bilateral & $(-)$ & $(-)$ & $(-)$ & Eye & $\begin{array}{l}\text { Necrotizing } \\
\text { vasculitis }\end{array}$ & PSL plus cyclophosphamide \\
\hline [6] & $\mathrm{F} / 19$ & Bilateral & $(-)$ & $(+)$ & $(-)$ & $(-)$ & Myositis & PSL $0.5 \mathrm{mg} / \mathrm{kg} /$ day \\
\hline [4] & $\mathrm{F} / 25$ & Left & $(+)$ & $(+)$ & $(-)$ & Joint & $\begin{array}{l}\text { Non-necrotizing } \\
\text { vasculitis }\end{array}$ & Infliximab \\
\hline [14] & $\mathrm{M} / 15$ & Bilateral & $(+)$ & $(-)$ & $(-)$ & $(-)$ & Myositis & $\begin{array}{l}\text { PSL } 40 \mathrm{mg} / \text { day. Recurrence at PSL } 10 \\
\mathrm{mg} / \text { day, switched to methotrexate }\end{array}$ \\
\hline [15] & $\mathrm{M} / 26$ & Bilateral & $(+)$ & $(+)$ & $(-)$ & $(-)$ & Myositis & $\begin{array}{l}\text { Recurrence at PSL10 mg+azathioprine } \\
2.5 \mathrm{mg} / \mathrm{kg} \text {, added Adalimumab } \\
\text { (effective) }\end{array}$ \\
\hline Current case & $\mathrm{M} / 38$ & Bilateral & $(-)$ & $(-)$ & $(-)$ & $(-)$ & $\begin{array}{l}\text { Nongranulomatous } \\
\text { myositis }\end{array}$ & PSL 30mg/day \\
\hline
\end{tabular}




\section{Discussion}

Muscular involvement in CD often manifests in the orbital muscles (16-22), whereas inflammatory myositis affecting limbs such as polymyositis have been only rarely reported in CD $(10,23)$. In 1979, Menard et al. reported the first case of muscle symptoms confined to the calf in a patient with CD (13). Christopoulos et al. named this manifestation "gastrocnemius myalgia syndrome", which is now considered a rare extra-intestinal complication of CD (6). The clinical features of reported cases of gastrocnemius myalgia syndrome are summarized in Table 2, revealing the lack of a marked difference in gender prevalence. Gastrocnemius myalgia syndrome typically affects the lower extremities bilaterally, and progression to the thigh has been reported (6). All patients with gastrocnemius myalgia syndrome lack an elevated serum creatine kinase level, which is a typical feature. Notably, in some cases, myalgia precedes gastrointestinal symptoms, and a history of CD has been absent at the onset of myalgia.

Prednisolone was effective in the symptomatic resolution in all but two cases. Two patients with a relapse of myalgia during prednisolone tapering were treated successfully by the additional use of immunosuppressing agents. Note that in two cases, myalgia was refractory to conventional immunosuppressing agents, and biologics such as infliximab and adalimumab were needed. Druschky et al. reported that the pathological features of myositis associated with $\mathrm{CD}$ included inflammatory cell infiltration that spared myofibers, concentrated in the perimysium and endomysium with a tendency to be distributed throughout the perivascular area (10). The pathological findings in several cases in Table 2 were described as vasculitis, not myositis. These findings, consistent with those in the present case, might partially explain the lack of an increase in the serum creatine kinase level in patients with gastrocnemius myalgia syndrome.

In conclusion, we herein reported the first case of gastrocnemius myalgia syndrome in a patient with CD in Japan. As in the current case, gastrointestinal symptoms might not be apparent during the early stages of gastrocnemius myalgia syndrome. Therefore, CD should be considered in the differential diagnosis of patients with myalgia of the lower extremities.

The authors state that they have no Conflict of Interest (COI).

\section{References}

1. Matsumoto T, Nakamura S, Jin-no Y, et al. Role of granuloma in the immunopathogenesis of Crohn's disease. Digestion 63: 43-47, 2001.

2. Lakatos PL, Fischer S, Lakatos L, Gal I, Papp J. Current concept on the pathogenesis of inflammatory bowel disease-crosstalk between genetic and microbial factors: pathogenic bacteria and al- tered bacterial sensing or changes in mucosal integrity take "toll"? World J Gastroenterol 12: 1829-1841, 2006.

3. Lakatos PL, Lakatos L, Kiss LS, Peyrin-Biroulet L, Schoepfer A, Vavricka S. Treatment of extraintestinal manifestations in inflammatory bowel disease. Digestion 86: 28-35, 2012.

4. Ullrich S, Schinke S, Both M, et al. Refractory central nervous system vasculitis and gastrocnemius myalgia syndrome in Crohn's disease successfully treated with anti-tumor necrosis factor-alpha antibody. Semin Arthritis Rheum 38: 337-347, 2009.

5. Basseri B, Enayati P, Marchevsky A, Papadakis KA. Pulmonary manifestations of inflammatory bowel disease: case presentations and review. J Crohns Colitis 4: 390-397, 2010.

6. Christopoulos C, Savva S, Pylarinou S, Diakakis A, Papavassiliou E, Economopoulos P. Localised gastrocnemius myositis in Crohn's disease. Clin Rheumatol 22: 143-145, 2003.

7. Dioszeghy P, Molnar M, Mechler F. Muscle involvement in Crohn disease. Orv Hetil 135: 1259-1261, 1994.

8. Disdier P, Swiader L, Harle JR, et al. Crohn's disease and gastrocnemius vasculitis: two new cases. Am J Gastroenterol 92: 880882, 1997.

9. Drabble EM, Gani JS. Acute gastrocnemius myositis. Another extraintestinal manifestation of Crohn's disease. Med J Aust 157: 318-320, 1992.

10. Druschky A, Heckmann J, Engelhardt A. Myositis-a rare complication of Crohn disease. Fortschr Neurol Psychiatr 64: 422-424, 1996.

11. Gilliam JH, Challa VR, Agudelo CA, Albertson DA, Huntley CC. Vasculitis involving muscle associated with Crohn's colitis. Gastroenterology 81: 787-790, 1981.

12. Hall MJ, Thomas WE, Cooper BT. Gastrocnemius myositis in a patient with inflammatory bowel disease. Digestion 32: 296-300, 1985.

13. Menard DB, Haddad H, Blain JG, Beaudry R, Devroede G, Massé S. Granulomatous myositis and myopathy associated with crohn's colitis. N Engl J Med 295: 818-819, 1976.

14. Mogul Z, Katz S, Bachman TR, Urmacher C. Isolated gastrocnemius myositis related to Crohn's disease. Gastroenterol Hepatol (N Y) 6: 453-455, 2010.

15. Vadala di Prampero S, Marino M, Toso F, Avellini C, Nguyen V, Sorrentino D. Isolated bilateral gastrocnemius myositis in Crohn disease successfully treated with adalimumab. Case Rep Gastroenterol 10: 661-667, 2016.

16. Pimentel R, Lago P, Pedroto I. Recurrent orbital myositis as an extra-intestinal manifestation of Crohn's disease. J Crohns Colitis 6: 958-959, 2012.

17. Biotti D, Toulemonde P, Brassat D, Bonneville F. Teaching neuroimages: Painful diplopia and Crohn disease: Think about orbital myositis. Neurology 87: e68-e69, 2016.

18. Onder O, Bilgin RR, Köşkderelioğlu A, Gedizlioğlu M. Orbital myositis: Evaluating five new cases regarding clinical and radiological features. Noro Psikiyatr Ars 53: 173-177, 2016.

19. Sachdeva A, Kramer N, Rosenstein ED. Orbital inflammatory disease: unusual presentation of enthesitis in an HLA-B27 spondyloarthropathy. Ocul Immunol Inflamm 20: 468-470, 2012.

20. Vargason CW, Mawn LA. Orbital myositis as both a presenting and associated extraintestinal sign of Crohn's disease. Ophthal Plast Reconstr Surg 33: S158-S160, 2017.

21. Verma S, Kroeker KI, Fedorak RN. Adalimumab for orbital myositis in a patient with Crohn's disease who discontinued infliximab: a case report and review of the literature. BMC Gastroenterol 13: 59, 2013.

22. Zenone T. Orbital myositis and Crohn's disease. Int J Rheum Dis 17: 481-482, 2014.

23. Leibowitz G, Eliakim K, Amir G, Rachmilewitz D. Dermatomyositis associated with Crohn's disease. J Clin Gastroenterol 18: 48-52, 1994. 
The Internal Medicine is an Open Access article distributed under the Creative Commons Attribution-NonCommercial-NoDerivatives 4.0 International License. To view the details of this license, please visit (https://creativecommons.org/licenses/ by-nc-nd/4.0/).

(C) 2018 The Japanese Society of Internal Medicine

Intern Med 57: 2001-2006, 2018 